\title{
Genetic Divergence Analysis in Indian mustard (Brassica juncea L.)
}

\author{
Sudheer Singh ${ }^{1}$, Ajeet Kumar Dwivedi ${ }^{1}$, Ashutosh $^{2} *$, \\ Omesh Kumar ${ }^{2}$ and Kamlesh Kumar ${ }^{1}$
}
${ }^{1}$ Department of Genetics and Plant Breeding, Narendra Deva University of Agriculture and Technology, Kumarganj, Faizabad (U. P), India
${ }^{2}$ Department of Genetics and Plant Breeding, Institute of Agricultural Sciences, Banaras
Hindu University, Varanasi (U.P.), India

*Corresponding author

\section{A B S T R A C T}

\section{Keywords}

Indian mustard, genetic divergence, $\mathrm{D}^{2}$ analysis and cluster analysis

Article Info

Accepted:

20 May 2018

Available Online:

10 June 2018
Sixty Indian mustard genotypes studied for genetic divergence using Mahalanobis's $\mathrm{D}^{2}$ statistics indicated the presence of wider genetic diversity among the material. Analysis of variance indicated that considerable genetic variability were existed among the 60 genotypes. On the basis of Tocher's clustering pattern, the genotypes were grouped into 9 clusters. According to the results, $\mathrm{C}$ I had the maximum no. of 16 genotypes, while the $\mathrm{C}$ IX and C VIII had 13 and 10 genotypes, respectively. Plant height, length of main raceme, 1000 -seed weight and siliqua on main raceme were the major contributors for genetic diversity among the genotypes with $57.25 \%, 21.63 \%, 20.86 \%$ and $8.32 \%$ respectively. The highest intra cluster distance was recorded for CVII (246.31) followed by C III (131.03) and C IX (127.63). The maximum inter cluster distance was observed between C VI and IX (2338.242) followed by C III and IX (2028.639), while the lowest in the C VIII and IX (274.3). The above results indicates that these genotypes have maximum genetic diversity and useful for developing a large number of seggregants through crossing programme by using maximum diverse genotypes.

\section{Introduction}

Rapeseed-mustard is a group of crops comprising rapeseed (toria, brown sarson and yellow sarson), cultivar of Brassica campestris; Indian mustard (Brassica juncea); black mustard (Brassica nigra) and taramira (Eruca sativa). Some exotic species of Brassiceae like gobhisarson (B. napus), Ethopian mustard or karanrai (B. carinata) and white mustard (Sinapis alba) have been brought into cultivation in India. The genus
Brassica is one of 51 genera of Brassiceae family. Brassica juncea $(\mathrm{n}=18)$ is an amphidiploid species derived from interspecific crosses between B. nigra $(\mathrm{n}=9)$ and $B$. rapa $(\mathrm{n}=10)$. Rapeseed-Mustard is the second most important oilseed crop of India (third most important in the World) and plays a significant role in Indian economy by contributing about $27.8 \%$ of the total edible oilseed production (Singh et al., 2010). Globally, India account for $19.3 \%$ and $11.1 \%$ of the world acreage and production. These 
crops are cultivated on an area 5.76 million ha. With a total net production of 6.79 million tonnes and with an average yield of 1184 kg/ha. (Agril.Stats.At a glance, 2016). The major growing states in India are Rajasthan (48\%), Haryana (12\%), MP (10\%), UP (9\%) and West Bengal (7\%) contributes $>80 \%$ of area and $>85 \%$ of production of mustard oil. It contains about 38 to 43 per cent oil which is golden-yellow in colour, fragrant and is considered to be the healthiest and nutritious cooking medium. Oil possess one of the best fatty acids profile (low saturated fatty acids (8\%), high monounsaturated fatty acids $(70 \%)$ and alpha linolenic acid (10\%), among the various vegetable oils, which reduces the risk of coronary heart diseases by almost $70 \%$. Removal of glucosinolates increases the nutritional quality of deoiled cake and makes it less pungent for consumption as fodder. During the past years, a major gain in its productivity has been achieved, but still there is a great scope for further enhancement in its productivity.

The estimated demand for vegetable oils is likely to be around 34 million tonnes by 2020 A.D., of which nearly 14 million tonnes is to be met out by the Rapeseed-mustard crops. The production can be enhanced through the development of high yielding varieties. Therefore, emphasis should be given to develop high yielding varieties with through hybridization followed by selection. Estimation of degree of divergence between biological population and computation of relevant contribution of different components to the total divergence is done completely. Genetic variability in respect to genetic diversity is the prerequisite for the crop improvement through selection of high yielding genotypes. Genetic diversity arises either due to geographical separation or due to genetic barriers to cross ability. The quantification of genetic diversity by biometrical approaches can help choose diverse parents for a successful hybridization programme. Genetic diversity plays an important role in plant breeding because hybrids between lines of diverse origin generally display a greater heterosis than those between closely related strains (Singh, 1986) which permits to select the genetically divergent parents to obtain the desirable recombination in the segregating generations (Uddin and Chowdhury, 1994). Selection of parents based on genetic divergence has become successful in several crops (Ashana and Pandey, 1980; Ananda and Rawat, 1984). Evaluation of genetic diversity is important to know the source of genes for a particular trait within the available germplasm (Tomooka, 1991). Therefore, the present investigation was carried out to determine the divergence among the different genotypes of Indian mustard.

\section{Materials and Methods}

An experiment was conducted at the research farm of Oilseeds Section, Department of Genetics and Plant breeding, N.D.U.A. \& T., Kumarganj, Faizabad, (U.P.) during rabi, 2011-12. Sixty four diverse genotypes of Indian mustard (B. juncea) were planted in Augmented Block Design with four popular check varieties viz., Vardan, Ashirwad, Kranti, and Maya. These genotypes exhibiting wide spectrum of variation for various agronomical and morphological characters, were obtained from the germplasm maintained at Oilseed section of Genetics and Plant Breeding Department. These lines were grown in single row plot of 5 meter length. Each block consisted of 10 entries plus 4 checks. The spacing between row to row and plant to plant was $30 \mathrm{~cm}$ and $15 \mathrm{~cm}$ maintained by thinning. On the basis of five randomly selected plants, data were recorded on days to maturity, plant height, primary and secondary branches plant ${ }^{-}$ ${ }^{1}$, length of main raceme, number of siliquae on main raceme, number of seeds siliqua $^{-1}$, 
seed yield plant $^{-1}, 1000$-seed weight, oil content (\%) except days to $50 \%$ flowering which was recorded on plot basis. Mahalanobis (1936) D² statistics was used for assessing genetic divergence among all the genotypes. The clustering of $\mathrm{D}^{2}$ values was done using Tocher's method as described by Rao (1952), while the intra and inter-cluster distances were calculated using the formula given by Singh and Choudhary (1985).

\section{Results and Discussion}

The analysis of variance revealed highly significant differences among the genotypes for all the eleven traits under study, reflecting presence of considerable variability and genetic worth of the genotypes. Thus, providing adequate scope for selection of superior genotypes aimed at utilizing exploitable variability for enhancing genetic yield potential.

Sixty four Indian mustard genotypes, based on Tocher's method were grouped in nine different clusters in Table-1, showed considerable amount of genetic diversity among genotypes for different character. Highest number of genotypes (16) were accommodated in C I followed by C IX (13), C VIII (10), C III (7) whereas C II, C IV, C V, $\mathrm{C}$ IV and C VII were oligo-genotypic. Such grouping of genotypes into clusters by Tocher's method are based on generalized distance which is statistic related to the coefficient of racial likeliness developed by Mahalanobis (1936) and Rao (1952). More precise clustering method is non-hierarchical Euclidean method (based on Wards minimum variance dendogram) which more critically identifies sub clusters of the main groups at different levels, thus offering additional opportunity to crop breeders, in more critically planning the hybridization programme, using diverse parents aimed at genetic enhancement of any crop species, including crop Brassicas.
The clustering pattern indicated that there was a lot of diversity among the genotypes and there was no relationship between the genetic and geographical diversity of the genotypes but the distribution of the genotypes was random and independent. This could be due to genetic drift, selection pressure and environmental effect which create morphological diversity rather than actual genetic distances. Similarly, the strains developed at one station were also grouped in different clusters which suggested that there might have been introgression of genes among the genotypes of various origins and operation of similar forces of selection. The present findings are in agreement with those obtained by Yadav et al., (1985), Thakur et al., (1989), Verma and Sachin (2000), Chaudhary and Joshi (2001), Gangapur et al., (2010), Goyat et al., (2012) and Singh et al., (2013) in Indian mustard.

The intra and inter-cluster $\mathrm{D}^{2}$ values are presented in Table-2, which indicated that maximum intra-cluster $\mathrm{D}^{2}$ values of 246.306 was observed for C VII followed by 131.03 for C III and 127.63 for C IX. The maximum inter-cluster distance was observed between $\mathrm{C}$ VI and C IX (2338.24) followed by C III and C IX (2028.64), C IV and C IX (1618.26) and C I and C IX (801.28). Large inter-cluster distance signifies that genotypes grouped in these clusters were different from the genotypes of other clusters for one or more characters, which made them so divergent from other.

Selection of diverse parents having most of the desirable characters from such clusters and using them in breeding programs is likely to produce more transgressive segregants and heterotic $\mathrm{F}_{1}$ 's when crossed. The inter-cluster distance was found to be minimum (274.3) between C VIII and C IX suggesting a close relationship between members of them and a low degree of diversity among the genotypes. 
Table.1 Clustering pattern of 64 genotypes on the basis of non-hierarchical Euclidean cluster analysis for 11 characters

\begin{tabular}{c|c|l|}
$\begin{array}{c}\text { Cluster } \\
\text { number }\end{array}$ & $\begin{array}{c}\text { No. of } \\
\text { genotypes }\end{array}$ & \multicolumn{1}{|c}{ Genotypes } \\
\hline I & 16 & $\begin{array}{l}\text { ISC-1-15, DIVYA-44, CJ-3761, KMR-10-2, ISC-1-8, NQR-8807-13, LES-43, NDR-25-2, NPJ- } \\
\text { 146, RRN-722, NDYR-32, NDYR-123-2, RH-0830, RH-58, RH-0735, CS-54 }\end{array}$ \\
\hline II & 6 & PUSA MUSTARD, NDYR-23, HUJM-08-12, NDYR-152, LES-42, NDYR-10 \\
\hline III & 7 & RH(OE)-0901, NDR-3-5, KMR-10-1, NDR-2004, RGN-286, ELM-3031, JMWR-945-2-2 \\
\hline IV & 4 & NDYR-8, URVASHI, NDR-8207, NDRS-2017 \\
\hline $\mathbf{V}$ & 2 & ACN-83, NDRE-7 \\
\hline VI & 1 & NDRE-4 \\
\hline VII & 5 & DRMR-IJ-31, NPJ-141, KM-9201, NDRS-2017-1, PR-2008-13, \\
\hline VIII & 10 & $\begin{array}{l}\text { NDWL-2003, ASHIRWAD, PRE-2007-17, KANTI, NDYR-20, KRANTI, RGN-73, MAYA, } \\
\text { VARDAN, RL-1359 }\end{array}$ \\
\hline IX & 13 & $\begin{array}{l}\text { NDYR-29, NDR-3-6, NDYR-28, BASANTI, KARGIL SELECTION, NDRS-2004, NDR-8208, } \\
\text { NDR-2001, PARASMANI, RKM (L) 10-2, RH (OE)-0902, NDR-190, PRB-2004-3 }\end{array}$ \\
\hline
\end{tabular}

Table.2 Estimates of average intra (diagonal) and inter-cluster distances for 9 clusters in Indian mustard

\begin{tabular}{|c|c|c|c|c|c|c|c|c|c|c|}
\hline $\begin{array}{c}\text { S. } \\
\text { No }\end{array}$ & Clusters & I & II & III & IV & V & VI & VII & VIII & IX \\
\hline 1. & I & 108.04 & 185.21 & 422.61 & 390.81 & 1693.73 & 5156.54 & 579.76 & 413.99 & 801.28 \\
\hline 2. & II & & 70.85 & 722.56 & 786.61 & 1587.61 & 4592.27 & 633.50 & 377.77 & 500.05 \\
\hline 3. & III & & & 131.03 & 412.59 & 3301.41 & 7938.96 & 1389.11 & 1333.39 & 2028.64 \\
\hline 4. & IV & & & & 97.79 & 2080.98 & 6267.42 & 697.03 & 827.31 & 1618.26 \\
\hline 5. & V & & & & & 49.93 & 1211.04 & 685.63 & 572.36 & 618.77 \\
\hline 6. & VI & & & & & & 0.00 & 3384.69 & 2928.83 & 2338.24 \\
\hline 7. & VII & & & & & & & 246.31 & 277.23 & 575.71 \\
\hline 8. & VIII & & & & & & & & 90.91 & 274.30 \\
\hline 9. & IX & & & & & & & & & 127.63 \\
\hline
\end{tabular}


Table.3 Cluster means values for seed yield and its component characters in Indian mustard

\begin{tabular}{|c|c|c|c|c|c|c|c|c|c|c|c|c|}
\hline $\begin{array}{l}\text { S. } \\
\text { No }\end{array}$ & Clusters & $\begin{array}{c}\text { Days to } \\
50 \% \\
\text { flowering }\end{array}$ & $\begin{array}{l}\text { Days to } \\
\text { maturity }\end{array}$ & $\begin{array}{l}\text { Plant } \\
\text { height } \\
(\mathrm{cm})\end{array}$ & $\begin{array}{l}\text { Primary } \\
\text { branche } \\
\text { s/ plant }\end{array}$ & $\begin{array}{c}\text { Secondary } \\
\text { branches/ } \\
\text { plant }\end{array}$ & $\begin{array}{l}\text { Length } \\
\text { of main } \\
\text { raceme } \\
(\mathrm{cm})\end{array}$ & $\begin{array}{l}\text { Siliquae } \\
\text { on main } \\
\text { raceme }\end{array}$ & $\begin{array}{l}\text { Seeds/ } \\
\text { siliqua }\end{array}$ & $\begin{array}{l}1000- \\
\text { seed } \\
\text { weight } \\
(\mathrm{g})\end{array}$ & $\begin{array}{c}\text { Oil } \\
\text { content } \\
(\%)\end{array}$ & $\begin{array}{c}\text { Seed } \\
\text { yield/ } \\
\text { plant } \\
\text { (g) }\end{array}$ \\
\hline 1. & I & 64.89 & 126.94 & 173.70 & 6.24 & 11.10 & 65.62 & 52.05 & 13.19 & 3.94 & 41.36 & 11.20 \\
\hline 2. & II & 69.34 & 127.17 & 169.29 & 5.21 & 8.41 & 60.39 & 47.62 & 12.31 & 3.69 & 42.03 & 7.33 \\
\hline 3. & III & 65.08 & 129.42 & 198.94 & 5.95 & 12.15 & 71.56 & 52.50 & 13.80 & 3.83 & 40.72 & 11.99 \\
\hline 4. & IV & 57.92 & 125.88 & 179.27 & 5.21 & 13.17 & 84.22 & 56.36 & 12.13 & 4.66 & 41.95 & 13.03 \\
\hline 5. & V & 51.92 & 116.38 & 126.81 & 5.11 & 12.63 & 72.59 & 45.84 & 14.06 & 3.11 & 41.76 & 9.54 \\
\hline 6. & VI & 47.30 & 110.13 & 98.97 & 5.28 & 16.33 & 50.42 & 28.79 & 9.86 & 3.21 & 40.97 & 7.83 \\
\hline 7. & VII & 58.50 & 128.63 & 149.92 & 4.44 & 8.85 & 79.60 & 44.69 & 13.50 & 4.56 & 41.15 & 11.18 \\
\hline 8. & VIII & 59.90 & 122.88 & 153.55 & 6.10 & 13.52 & 65.18 & 47.04 & 12.79 & 3.70 & 41.17 & 10.70 \\
\hline 9. & IX & 64.95 & 124.34 & 145.09 & 4.65 & 9.30 & 56.99 & 41.72 & 13.47 & 4.05 & 41.11 & 7.59 \\
\hline & Mean & 59.98 & 123.53 & 155.06 & 5.36 & 11.72 & 67.39 & 46.29 & 12.79 & 3.86 & 41.36 & 10.04 \\
\hline
\end{tabular}

Table.4 Percent contribution of different characters towards genetic divergence in Brassica juncea

\begin{tabular}{|l|c|}
\hline \multicolumn{1}{|c|}{ Characters } & Per cent contribution (\%) \\
\hline Days to 50\% flowering & 0.82 \\
\hline Days to maturity & 1.34 \\
\hline Plant height (cm) & 57.25 \\
\hline Primary branches/ plant & 4.00 \\
\hline Secondary branches/ plant & 12.44 \\
\hline Length of main raceme (cm) & 21.63 \\
\hline Siliquae on main raceme & 8.32 \\
\hline Seeds/ siliqua & 1.25 \\
\hline 1000-seed weight (g) & 0.28 \\
\hline Oil content (\%) & 1.10 \\
\hline Seed yield/ plant(g) & 0.55 \\
\hline
\end{tabular}


Since the magnitude of heterosis largely depends on the degree of genetic diversity among parents and therefore, selection of parents from these clusters should be avoided for combination breeding. Cluster mean values of 11 characters are furnished in Table3. High range of mean values among the clusters was noted for all the characters. The genetic differences between the clusters were reflected by cluster mean differences also. The maximum mean values for characters viz. Days to maturity and plant height were recorded in C III, whereas, C IV was found superior for most of the traits like length of main raceme, siliquae on main raceme, 1000seed weight and Seed yield/plant. Maximum number of seeds per siliqua was observed in C V, while C II was observed to be superior for Oil content (\%) and Days to 50\% flowering.

The genotypes accommodated under cluster $\mathrm{C}$ $\mathrm{I}$ and $\mathrm{C}$ IV were found higher mean for primary as well as secondary branches per plant. Based upon the mean performance of different clusters, it would be appropriate to use the genotypes grouped in C II and C IV in crossing programme to get desirable recombinants for oil content, seed yield/plant and its most important components and for getting genetic variability.

To get desirable plant height and early maturity the members of C III can be utilized in crossing programme. Since, some clusters had higher inter-cluster distances among them, crossing between members of these clusters would result in increased heterosis and isolation of desirable recombinants/transgressive segregants in the segregating generations.

The relative contribution of each character towards total diversity has been presented in Table-4. Plant height (57.25\%) contributed maximum towards divergence followed by
Length of main raceme (21.63), secondary branches per plant (12.44\%), Siliquae on main raceme $(8.32 \%)$ and primary branches per plant $(4 \%)$. While the contribution from number of Days to maturity (1.34\%), Seeds/ siliqua (1.25\%), Oil content (1.10\%), Seed yield/ plant (0.55) and 1000-ssed weight $(0.28 \%)$ were low in magnitude. The plant height contributed highest $(57.25 \%)$ to the total divergence.

Similarly Gangapur et al., (2010) also indicated that number of secondary branches per plant attributed maximum per cent towards divergence. In contrast Shathi et al., (2012) indicated that oil content, 1000 seed weight and yield per plant contributed lowest to the total divergence.

The characters having great contribution to total divergence were responsible for genetic diversity in the present experimental materials. This indicated that the parents selected for hybridization on the basis of these characters would result into development of transgressive recombinants with high Heterosis. Similar results were obtained by Verma and Sachan (2000); Goswami and Sheikh (2003); Patel et al., (2006).

In the present study, length of main raceme, siliquae on main raceme and 1000-seed weight are among the phenotypic traits contributing towards seed yield per plant and can be used as indices for future breeding in cluster IV.

Thus, crosses between the genotypes of cluster IV with that of cluster V would exhibit high heterosis and is also likely to produce new recombinants with desired traits in Indian mustard. This shows that cluster comprising only one cultivar with specific traits could also be used in hybridization programme for exploiting hybrid vigour as reported by Saini and Kaicker (1987). 


\section{References}

Anand, I. J. and D. S. Rawat. 1984. Genetic diversity, combining ability and heterosis in brown mustard. Indian $J$. Genet. Pl. Breed., 41(2): 226-234.

Ashana, A.N. and Pandy, V.K. 1980. Genetic divergence in linseed.Indian J. Genet. Pl. Breed., 40: 247-250.

Chaudhary, B. R. and Joshi, P. 2001. Genetic diversity in advanced derivatives of Brassica interspecific hybrid. Euphy., 121(1): 1-7.

Gangapur, D.R., Prakash, B.G., Hiremath, C.P. 2010. Genetic Diversity Analysis of Indian Mustard (Brassica juncea L.). Elect. J. of Pl. Breed., 1(4): 407-413.

Goswami, P.K. and Sheikh, F.A. 2003. Genetic divergence analysis in Indian mustard. Ann. Agril. Res., 27: 187-190.

Goyat, B., Singh, D., Avtar, R. and Singh, A. 2012.Genetic divergence in elite gene pool of Indian mustard (Brassica juncea (L.) Czern \& Coss.). Research on Crops., 13(2) 1102-1104.

Mahalanobis, P. C. 1936. On the generalized distance in statistic.Proc. Nat. Inst. Sci., 2: 49-55.

Patel, J.M., Patel, K.M., Patel, C.J. and Prajapati, K.P. 2006. Genetic variability of divergence in Indian mustard.Indian J. Genet., 66: 49-50.

Rao, C.R. 1952. Advanced statistical method in biometric research. John Wiley and Sons Inc., New York.

Shathi, D.A., Arifuzzaman, M., Biswas, B.K., Hasanuzzaman, M., Azad, A.K. 2012. Genetic divergence in mustard (Brassica spp. L). African J. Plant Sc., 6(8): 239-243.

Singh, A., Avtar, R., Singh, D., Sangwan, O., Balyan, P. 2013. Genetic variability, character association and path analysis for seed yield and component traits under two environments in Indian mustard.J. Oilseed Brass., 4(1): 43-48.

Singh, D., Arya, R.K., Chandra, N., Niwas, R. and Salisbury, P. 2010. Genetic diversity in relation to seed yield and its component traits in Indian mustard (Brassica juncea L. Czern and Coss). J. Oilseed Brassica., 1(1): 10-22.

Singh, H. 1986. Genetic variability, heritability and drought indices analysis in Brassica species.J. Oilseeds Res., 3(2): 170-177.

Singh, R.K. and Chaudhury, R.D. 1985. Biometrical methods of quantitative genetic analysis. Haryana J. Hortic. Sci., 12: 151-156.

Thakur, H.L., Zarges, M.A. and Rana, N.D.1989. Heterosis in relation to genetic divergence and specific combining ability in Indian mustard.Indian J. of GeneT. and Plant Breed., 49(2): 233-236.

Tomooka, N. 1991. Genetic diversity and landrace differentiation of mungbean (Vigna radiata). An evaluation of its wild relatives as breeding materials. Tech. Bull. Trop. centre, Japan No. 28. Ministry of Agroforestry and Fisheries, Japan.

Uddin, M. J. and Chowdhury, M.A.Z. 1994. Genetic divergence in mustard. Bangladesh J. Genet. Pl. Breed., 7(2): 23-27.

Verma, S.K. and Sachan, J.N. (2000).Genetic divergence in Indian mustard (Brassica juncea (L.) Czern and Coss.).Crop Res., 19(2): 271-276.

Yadav, T.P., Kumar, K., Thakral, S.K. and Yadav, A.K. 1985. Genetic divergence, its relationship with heterosis and characters associating among seed yield and its components traits in Indian mustard. Journal of Oilseeds Res., 2: 163-173. 


\section{How to cite this article:}

Sudheer Singh, Ajeet Kumar Dwivedi, Ashutosh, Omesh Kumar and Kamlesh Kumar. 2018.

Genetic Divergence Analysis in Indian mustard (Brassica juncea L.). Int.J.Curr.Microbiol.App.Sci. 7(06): 2496-2503. doi: https://doi.org/10.20546/ijcmas.2018.706.296 